Seuralla on ollut onni saada esimiehiksi pitkäaikaisesti tehtäväänsä sitoutuneita henkilöitä: T.J. Wuorenrinne, Urpo Harva, Aulis Alanen, Jukka Tuomisto, Antti Kauppi ja Anja Heikkinen. Vaikka seuran johtokunnan nimilista on ollut varsin miesvoittoinen, on tässä tapahtunut muutos. Naisten osuus ja rooli seuran toiminnasta on nykyisellään vahva. Näin pitää ollakin: kun yliopistojen jatkotutkintojen suorittajista lähes kaikilla opintoaloilla selvästi yli puolet on naisia, näkyy heidän panoksensa myös aikuiskasvatuksen eri osa-alueilla.

\section{Rainer Aaltonen}

\section{Viitteet}

1. Vapaan sivistystyön järjestöt ovat itse köyhiä, joten ainakin viime vuosikymmeninä tuki lienee henkistä laatua.

2. Vapaan sivistystyön/ Aikuiskasvatuksen vuosirkertojen teemoista ks. wikipedia: Aikuiskasvatuksen vuosikrija.
3. Idean aikuiskasvatukselliset toimijat yhdistä västä newsletterista sai Kansanvalistusseuran silloinen pedagoginen johtaja Pentti Yrjölä. Tutkimusseuran esimiehen, apulaisprofessori Jukka Tuomiston rohkaisemana aloitetta alettiin jalostaa tieteelliseksi lehdeksi. Lehden kannattavuus rakennettiin isoille könttätilauksille, joista enin osa saatiin vapaasta sivistystyöstä, kuten Kansalais- ja työväenopistojen liitosta sekä muutamasta opintokeskuksesta. Lehden ensimmäiseksi päätoimittajaksi tuli Jukka Tuomisto ja toimitussihteeriksi Pentti Yrjölä. Toimitus oli ja on edelleen Kansanvalistusseurassa. Lehden tähänastiset päätoimittajat: http://www.aikuiskasvatus.fi/

4. Ks. tarkemmin: http://www.protsv.fi/ats/dokumentteja/muut/ats_historiikki_rainer_aaltonen.pdf

\section{Lisää bibliografioista:}

http://www.protsv.fi/ats/dokumentteja/muut/ ats_historiikki_rainer_aaltonen.pdf

\title{
Aikuiskasvatusta etsimässä
}

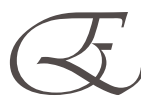
opillinen Yhdistys ja nykyinen Aikuiskasvatuksen Tutkimusseura täyttää 7. joulukuuta 70 vuotta. Siinä, missä 70 vuotta sitten oltiin huolissaan koko kansan koulutuksesta ja sivistyksestä, keskitytään nykyään työikäisten jälleenkoulutuksen ja työssäoppimisen problematiikkaan; miten saada ihmiset pysymään työelämässä pidempään ja vastaamaan radikaalisti muuttuneisiin työelämän vaateisiin. Miten saada työntekijän koko potentiaali käyttöön ja kuinka tehdä se mahdollisimman kustannustehokkaasti. Tehokkuusajattelu on ymmärrettävää yritysmaailmassa, mutta jotta tästä trendistä ei tulisi ainoa aikuiskasvatuksen suuntaa ja tutkimusta määrittävä kompassi

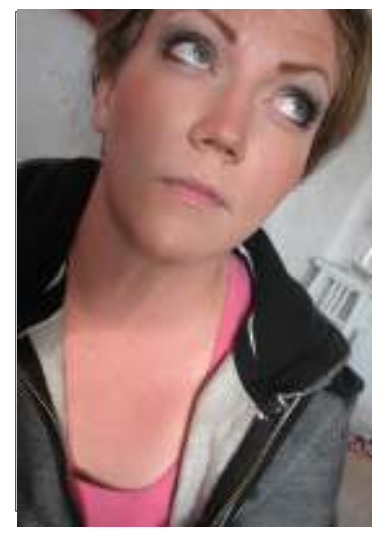

olisi mielestäni hyvä pysähtyä miettimään, mitä aikuiskasvatuksen olisi oikeasti hyvä pitää sisällään ja mitkä elementit tulisi asettaa kriittisen tarkastelun alle.

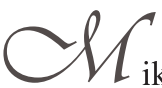
vatuksesta oman tieteensä ja miksi sitä halutaan opiskella? Lapin yliopiston tuoreen opinto-oppaan selaaminen ja vertailu yleisen kasvatustieteen kanssa ei tuota yllä mainittuun kysymykseen kovin tyhjentävää vastausta. Aikuiskasvatus ei poikkea mainittavasti yleisen kasvatustieteen opinto-ohjelmasta. Itse asiassa, aikuiskasvatus ei profiloidu juuri mitenkään jos opinto-oppaaseen on uskominen. Aikuiskas- 
vatukseen liittyy kuitenkin paljon sellaisia erityispiirteitä, jotka antavat perustelut pitää aikuiskasvatusta omana tieteenään. Itse valitsin viime syksynä aikuiskasvatustieteen pääaineekseni kysyttyäni neljän vuoden ajan työssäni kansalaisopiston opettajana, minkälainen on hyvä aikuiskasvattaja. Lapin yliopistossa vapaa sivistystyö ei kuitenkaan ole kovinkaan merkittävä, jos katsoo kurssitarjontaa. Aktiivinen kansalaisuus ja vapaa sivistystyö on ainoa kurssi, joka antaa mahdollisuuden perehtyä edes pintapuolisesti vapaaseen sivistystyöhön.

Pelkkänä kirjatenttinä suoritettava kurssi ei kuitenkaan riittävästi kata yhtä mielestäni keskeistä aikuiskasvatuksen osaa. Tämä ilmiö ei ole myöskään ainutlaatuinen. Helsingin yliopistossa Asko Kauppinen ja Elina Manninen pohtivat samaa puutetta kaksi vuotta sitten (Aikuiskasvatus 2/ 2008). Tällainen painotus jättää kylmäksi ne, jotka peräänkuuluttavat aikuisuuden ja aikuisen oppijan tutkimista koko yhteiskunnan sekä eliniän laajuisesti ja mittaisesti.

Mielestäni koulutuksessa tulisi ottaa huomioon kaikkien nykyisten ja tulevien aikuisten koulutukselliset ja kasvatukselliset tarpeet, eikä keskittyä pelkästään työikäisiin ja -kykyisiin yksilöihin. Aikuiskasvatus ei nimittäin sanana erittele tai jätä ulos ketään. Ei varmaan haittaisi jos kurssitarjonnasta löytyisi kursseja, jotka käsittelisivät esimerkikisi kolmanteen ikään ja ylikin ehtineitä oppijoina, vammaisten aikuisten kasvatuksellisia tarpeita, mielenterveyssektorin tai vankeinhoitolaitosten kanta-asiakkaiden elämänlaadun ja yhteiskunnalisen aseman parantamista, maahanmuuttajien parempaa integrointia ja niin edelleen. Toimiva ja terve yhteiskunta tarvitsee kaikkia jäseniään. Sillä ei ole varaa marginalisoida kaikkia yllämainittuja ryhmiä. Aikuiskasvatuksen pitäisi tässä olla suunnan näyttäjä, ei akateeminen pässi talouskasvuajattelun narussa.

Toinen ilmeinen puute on pedagogisten opintojen eksklusiivisuus; muiden kuin luokanopettajaopiskelijoiden täytyy läpikäydä tiukka valintaprosessi halutessaan lukea opettajan pedagogiset opinnot laajana sivuaineena. Mielestäni kuitenkin vähintään niillä, jotka opiskelevat mitä tahansa kasvatustieteiden haaraa, täytyisi olla automaattinen oikeus noihin opintoihin. Ihmetyttää, miksi opettajan pedagogisten opintojen opintooikeus on päätetty myöntää vain harvoille ja valituille, vaikka niiden suorittaminen enemmän kuin todennäköisesti helpottaisi työnhakua ja paran- taisi kasvatustieteilijän asemaa työmarkkinoilla huomattavasti niin palkkauksen kuin työpaikan vakituisuudenkin suhteen. Tämä epätasa-arvoistava asetelma pitäisi pikimmiten purkaa ja pedagogiset opinnot vapauttaa suuremmalle joukolle.

Riippuen omista mielenkiinnon kohteista ja urahaaveista Lapin yliopiston aikuiskasvatuksen opiskelija voi kuitenkin sivuainevalinnoillaan räätälöidä omaa tutkintoaan lähes loputtomasti. Tänä syksynä sivuainetarjontaa kartutti vielä uusi aine: globaalikasvatus. Toistaiseksi suppeana luettava sivuaine saattaa kuitenkin jatkossa saada pääaineen statuksen. Lapin yliopiston uusi motto: 'Pohjoisen puolesta, maailmaa varten" antaisi itse asiassa olettaa, ettei globaalikasvatuksen tie suppeasta sivuaineesta täysikasvuiseen maisterinohjelmaan olisi edes kovin pitkä. Koska globalisoituvassa maailmassa tarvitaan moniosaajia, jotka osaavat navigoida niin kotimaisilla kuin kansainvälisilläkin areenoilla, on globaalikasvatus oiva lisä sivuainetarjontaan. Pienryhmäopetuksena ja keskusteluun perustuvina luentoina opetettava aine haastaa opiskelijan aitoon, itsenäiseen ajatteluun ja mielipiteen muodostamiseen. Tämän opetustavan soisi itse asiassa vakiintuvan useammillekin kursseille.

Niin hyvässä kuin pahassakin Lapin yliopiston on kuitenkin Jyväskylän pohjoispuolella ainoa yliopisto, joka tarjoaa aikuiskasvatusta pääaineena. Koska Lapin yliopisto tässä mielessä kattaa puoli Suomea, on erikoista, ettei aikuiskasvatuksella ole vielä omaa professoria. Tältä rintamalta kuuluu kuitenkin lupaavia uutisia: Lastu ry, Lapin yliopiston kasvatustietelijöiden oma ainejärjestö, tapasi dekaani Kyösti Kurtakon hiljattain ja tuloksena saatiin muun muassa lupaus aikuiskasvatuksen professorin viran hakuun panemisesta keväällä 2011. Toiveissa on, että virka saadaan täytettyä syksyyn 2011 mennessä. Tämä kehitys vahvistanee aikuiskasvatuksen jalansijaa pienehkössä yksikössämme ja turvaa aikuiskasvatuksen pääaineen statuksen yliopistossamme vastakin.

\section{Terhi Joki}

Kirjoittaja on aikuiskasvatuksen toisen vuoden opiskelija Lapin yliopistossa. 